\title{
INTERDISCIPLINARY INNOVATION CAMP FOR NURSING AND ENGINEERING STUDENTS AT WNUAS
}

\author{
Eivind Standal Husabo, Dagrun Kyrkjebo, \& Joar Sande \\ Western Norway University of Applied Sciences (Norway)
}

\begin{abstract}
Learning outcome descriptions from the Norwegian qualifications framework for lifelong learning expects students to get acquainted with innovation, entrepreneurship and innovation processes. Western Norway University of Applied Sciences (WNUAS), in cooperation with Junior Achievement Sogn og Fjordane, organizes interdisciplinary innovation camps for nursing and engineering students. This has been an ongoing process since 2014 with one innovation camp every year. The innovation camp is organized by staff from WNUAS, and the student assignments are provided by local businesses and organizations. These businesses and organizations are present and available for student guidance during the innovation camp. In total we have had 20 different assignments from 12 businesses and organizations since 2014. The aim of the study is to find out about the students learning outcome from innovation camp as a strategy for learning, and to evaluate and improve the innovation camp concept. 6 students participated in the study through a focus group interview, and 71 participated through an online survey. Findings in this report shows that the students were satisfied with innovation camp as a method for learning, and they describe their own learning outcome as good. They regard innovation camp as a diverging learning method that varies from the more traditional methods of learning. An evaluation study from the innovation camp shows that students lack a common understanding of innovation and entrepreneurship before participating at the event. The students also found that the assignments were too limited, hence that they were not challenging enough for creative thinking. This report leads to several conclusions in order to improve upcoming innovation camps at WNUAS. The improvements can be separated into two categories: 1. The students needs to be better prepared for the event. 2 . The assignments need to be more open.
\end{abstract}

Keywords: Innovation, entrepreneurship, higher education, pedagogical model, innovation camp.

\section{Introduction}

Entrepreneurship in education as a strategy for learning comes with many facets and variations. In order to understand the concept, we need, first of all, to look into what could be a common understanding of the phenomenon on an international basis. The European commission defines entrepreneurship in education as a dynamic and social process where individuals, alone, or in cooperation with others identify opportunities, and does something about them by transforming opportunities into practical and goal orientated activities (KD-KRD-NHD 2004). The context of these activities could either be social, cultural or economic.

This study is based on the Norwegian system for entrepreneurship in education, and one specific program delivered by Junior Achievement Norway: innovation camp. The aim of the study is to find out more about the students learning outcome from participation in our innovation camps, and to improve upcoming innovation camps based on the students experiences and learning outcome. (Ødegård 2014) defines entrepreneurship as a multidisciplinary phenomenon where experiential learning and interaction between subjects are important strategies for learning. Entrepreneurship as a learning strategy will also include interaction with external actors outside the education system, and they could include both local, regional, national and global actors (Ødegård and Ask 2014). Examples of such actors could be businesses, non-profit organizations, governmental organizations and business advisors. The purpose of introducing entrepreneurship to the educational system is to enable the students to master changes and restructuring in a future perspective related to professional practice and the ability to participate in the society. Another important aspect related to entrepreneurship in education is experiential and action based learning. Ødegård (2003) defines entrepreneurship in education as action based learning in a social 
context, with the individual itself as an actor in the learning process. In this context the personal characteristics, abilities, knowledges and skills for the individual will create the foundation and direction for the learning process. In general there are four motives for introducing entrepreneurship in education: 1) the foundation motive - will stimulate to creation of new enterprises, 2) the district political motive creation of jobs and opportunities in rural areas, 3) the labor market motive - creation of new jobs / providing students skills for the future and 4) the educational motive - give the students the opportunity to work with innovation, creativity, business startup and entrepreneurship as strategies for learning (Ødegård 2000).

According to Leffler (2006) there is a distinct separation between education about entrepreneurship, education for entrepreneurship and education through entrepreneurship. The first one has exclusively a knowledge accumulating purpose, and the last one emphasizes an entrepreneurial learning process based on experiential and problem based learning. The learning outcome could be reinforced by a network oriented strategy with extended access to information and resources for the students. This way of facilitating education will create an arena for learning that is closer to the real world (Järvi 2012).

Learning outcome descriptions from the Norwegian qualifications framework for lifelong learning expects students to get acquainted with innovation, entrepreneurship and innovation processes (Kunnnskapsdepartementet 2014). Based on the learning outcome descriptions, the authors of this article decided to arrange innovation camps for nursing and engineering students at WNUAS. Innovation camps in higher education is not a new phenomenon. The program has been delivered by Junior Achievement Norway throughout the entire Norwegian educational system since early 2000 (UE-Norge 2017). The new perspective in this article is the interdisciplinary context for innovation camps in higher education. This has been rarely done in Norway. Mixing students in interdisciplinary groups, and give them the opportunity to solve given assignments by local businesses and organizations, will create a unique learning situation. The students are challenged to come up with solutions together, and to advise each other's from their own professional perspectives. In second hand, the solutions provided by the students can lead to implemented strategies by the assignment providers in their own businesses and organizations. The basics of an innovation camp is to let students and local businesses, or organizations, work together on given assignments. The assignment itself is given by the local business or organization, and it needs to be an experienced challenge for the provider of the assignment.

Annual interdisciplinary innovation camps have been provided for the nursing and engineering students at WNUAS since 2014. One of the main intentions is to let the students learn from each other by working together in groups. This will lead to a better understanding of each other professions. In a future perspective this can also lead to a better cooperation and understanding between nurses and engineers related to new developments and solutions for e.g. welfare technology and in treatment of patients. In a future perspective we believe that the different professions must depend on mutual competences, and the innovation camps might be a way to create mutual understanding between different professions. In total the students have been exposed to 18 different assignments since the beginning in 2014 . There is a huge variety in assignments, from measures that will prevent spreading of infections in kindergartens to a new hospital bed that will prevent nurses to be worn out due to strain from heavy lifts. The assignment from 2018 is especially interesting, where the students were told to build a healing garden for patients with dementia. This assignment was given by a local municipality administration. The second assignment this year was finding out how to prevent obesity among psychiatric patients.

Boge (2012) concludes that interdisciplinary innovation camps will provide a good learning outcome if the process is well organized. At WNUAS we prepare the students for the innovation camps by giving them lectures about creativity, innovation and entrepreneurship prior to the innovation camp. The preparation includes a practical creative activity. We also provide them with knowledge about the actual assignments, and knowledge about the innovation camp structure and how it's organized. To remove the students from what we perceive as an ordinary education situation could be helpful in order to promote creativity and innovation in a teambuilding situation (Bager 2008). Experiences with innovation camps throughout the Norwegian educational systems shows that some students becomes "security seekers" when they are exposed to the entrepreneurial activities (Hasleberg and Hagen 2016). These students will often withdraw from the actual learning situation, and not participate fully to the situation. This is also an experience that we have had with our innovation camps at WNUAS. A solution to this challenge might be to introduce "peer students" (Hasleberg and Hagen 2016). This could be students who have experience with entrepreneurship as a strategy for learning, or students from former innovation camps. 


\section{Method}

The collection of data in this study is based on two separate sources. The qualitative part was conducted as a focus group interview with 6 participating students from WNUAS using an explorative approach. We used an open interview guide with 4 questions. A qualitative approach is useful when you want to get an in-depth study of a phenomenon, and to get a better understanding (Kvale, Brinkmann et al. 2009). The method is also useful according to present the variety and details in your material. Participating at the innovation camp 2017 was the inclusion criteria for participating as an informant to the study. The main question that we wanted an answer to is: what do nursing and engineering students experience from participating at interdisciplinary innovation camps, and how do these experiences prepare the students for problem solving in the future?

In addition to the qualitative part we also introduced a simple questionnaire for the participating students at the innovation camp 2019. The questionnaire consisted of 9 questions and 71 of 99 students gave their feedback. The questionnaire contained three focus areas: a) Learning outcome for the students b) How the students experienced the innovation camp c) How the students experienced the assignment, the assignment providers and the academic content. Questions 1. to 8. were graded by the scale 1 to 6 , where 6 is the highest score and 1 is the lowest. Question nr. 9 was text based, where the students could write comments about the innovation camp.

Data from the qualitative part is processed interpreted in a phenomenological-hermeneutical tradition (Polit and Beck 2018) inspired by Graneheim og Lundman (Graneheim and Lundman 2004). The analyzing process started during the interview, and was continued through the transcription process. Data was systematized regarding to the research questions, and meaningful units were withdrawn. Based on this we made a concentration of text where we divided the material into 3 categories: a) A common understanding of the term innovation $b$ ) The challenge of working interdisciplinary c) The assignments did not challenge the students enough in an interdisciplinary manor.

The questionnaire was analyzed by transferring the students scores into percentage based on the scale 1 - 6 where the upper part of the scale is the score 4-6 and, the lower part is 1-3. We divided the text based answers in the questionnaire into positive and negative feedbacks. The research was completely anonymous and volunteer, and approved by the Norwegian center for research data.

\section{Results}

The lack of a common understanding for the term innovation is obvious among the participants in the study. They have an understanding of innovation based on their own occupational perspective. The nursing students describes innovation as scary, referring to an automated health care that will make them redundant in the labor market. They also describe innovation in health care as difficult due to economy, knowledge and the willingness to make changes. The engineering students has a different perspective on this, since innovation is a part of their job on daily basis.

It is also clear that the interdisciplinary cooperation between the groups are challenged by the lack of knowledge to each other's professions. Both groups can identify the need of more professional cooperation between the two groups, and they clearly see the innovation camp concept as a way to learn how to cooperate with other professions. The cross curricular knowledge is also useful, according to the participants. They will get a deeper understanding of each other's professions, and professional challenges. The participants also describe the learning outcome from innovation camps as an improvement to the cooperative problem solving process for future professional practice.

Most of the participants in the study agreed to the fact that the innovation camp assignments did not encourage enough to creativity and innovation processes. The assignments were to detailed, and there were given to many descriptions and assumptions of a possible outcome. It's clearly expressed by the participants that a learning process focused on creativity and innovation will demand more open assignments and must give the students a better opportunity to create their own ideas and solutions.

The results from the questionnaire shows that $81 \%$ of the participants are in the upper part of the scale when it comes to an overall evaluation of the innovation camp. $73 \%$ of the students scored in the upper part of the scale on evaluating the innovation camp assignments, and $70 \%$ scores in the upper part regarding to their own learning outcome. By summing the negative responses from the text based part questionnaire we found that the assignment providers were to critical, which lead to obstructing the students motivation for being creative. We also found that the assignment providers need to spend more time giving feedback to the students. The positive feedbacks from the participants told us that the students have a need to get more opportunities for creative and innovative working methods. Some of the participants describes their learning outcome as highly valuable, and they regard the innovation camp as a good opportunity to get to know new people and other professions. 


\section{Discussions and conclusions}

Entrepreneurship and innovation camps as a strategy for learning aims to bring students and local businesses / local organizations closer together by creating a learning arena for creativity and innovation (KD-KRD-NHD 2009, Ødegård and Ask 2014, UE-Norge 2017). These intentions can be difficult to achieve when the students are lacking a common understanding for innovation and entrepreneurship. Innovation camps with open assignments will challenge the students to be innovative, even though it could seem difficult for some of the students to participate. In order to cooperate across professional borders, one needs to create a common language and a common understanding dispute the fact that the two professions have their own separate languages and terms. It is important for the learning process is to accomplish a common understanding for the given assignments at the innovation camp, and how to move on into the problem solving process. During the innovation camp, and the following evaluation, the students stated that they got a better insight in each other's professions. This shows that interdisciplinary innovation camps can be a good strategy for cross curricular learning, and training for interprofessional cooperation in a future perspective. The students also expressed that the learning outcome could be useful for them in a future professional practice. They realize that in the future the demand of skills related to interdisciplinary collaboration will be important, and the innovation camp concept is a good learning arena to prepared for this.

Hasleberg and Hagen (2016) points out that some students will find it difficult to remove themselves from the comfort zone in order to work with innovation and creativity. Regarding the two professions in this study, one can say that the engineers are used to technical drawings and calculations, and on the other side, the nursing students are used to medical descriptions and plans for health care. If the students are not used to it, these habits of learning can be hard to break. If we take into consideration that the innovation camp assignments not were open enough, it will be even more difficult for the students to enter the arena of creative and innovative work process.

The fact that the assignment providers were present and coached the students through a problem solving process lead to a student active learning process where the students got the opportunity to ask open questions. Harland (2003) states that according to problem-based learning the teacher is not a teacher in a traditional sense, but more like a mentor who levels with the students and give advises in a common process of developing solutions. One could also use "peer students" as advisors for the innovation camp, based on their former experience with entrepreneurship and innovation (Hasleberg and Hagen 2016). This learning process corresponds with the sociocultural view of learning where the learning process is common for all, and the participants are equally valuable with their unique level and form of competence (Dysthe 1999). In this context, knowledge will be produced through interaction, and there are none given answers.

The preparation of students prior to the innovation camp is important in many ways. First of all the students will gain insight about the innovation camp concept, and secondly they will be given examples of innovations, and professional updates related to the innovation camp assignments. It is important to see the preparation of students in conjunction with the upcoming activities and tasks during the innovation camp itself. Tuckman and Humphreys (1965) theory about working in groups with the phases "forming, norming and performing" is relevant in this context. We also have to take into consideration the group dynamics, and be prepared for conflicts, insecurity and other group related challenges. A major objective is to involve all students and all groups to the learning space (Dysthe 1999).

As professional trainers in entrepreneurship and innovation we have learned a lot from our experiences with interdisciplinary innovation camps since the beginning in 2014. The innovation camp assignments need to be more open and we need to do a better quality check of the actual tasks and assignments. We must also give the students more opportunities to get to know each other better. This can be done during the preparation prior to the event. That being said, we also found that the preparations are more important than we thought in the beginning. During the preparations we need to clarify expectations from all sides, both students, lecturers and assignment providers. From the lecturers point of view it is important to clarify for the students their expectations of participation in every part of the innovation camp. It is also important to secure the students common understanding of the terms creativity and innovation. Choosing assignment providers is an important phase in the planning section of the work. We need to take several perspectives into consideration while choosing our partners: Does the partner have the recourses to become an assignment provider? Will their business / organization and possible assignment be motivating in the students work process? Is it possible to make the assignment open enough for the innovation camp concept? Do they have time to give the students proper feedbacks on their work? For further innovation camps we concluded that the creativity lecture as part of the preparation is important in order to put students in a creative mode. Regarding the upcoming innovation 
camp in 2020 we are considering to try a new concept with only one assignment provider. This might lead to a more common perception of the assignment, and reduce the competition among assignments. Since the students don't get to choose themselves among the assignments, we have learned that they sometimes are motivated to solve one of the assignments that's not given to their group. By letting all students work with the same assignment, one can eliminate factor of assignment competition, and hopefully achieve more motivated students.

\section{References}

Bager, T. (2008). The Camp Model-an innovative way of teaching entrepreneurship. IntEnt Conference.

Boge, K. (2012). "How to facilitate the learning of creativity: thinking "outside the box" and beyond textbook solutions." Development and Learning in Organizations: An Intenational Journal (6): 14-16.

Dysthe, O. (1999). "Ulike teoriperspektiv på kunnskap og læring." Bedre skole.

Graneheim, U. H. and B. Lundman (2004). "Qualitative content analysis in nursing research: concepts, procedures and measures to achieve trustworthiness." Nurse Education Today (2): 105-112.

Harland, T. (2003). "Vygotsky's Zone of Proximal Development and Problem-based Learning: Linking a theoretical concept with practice through action research." Teaching in Higher Education (2): 263-272.

Hasleberg, H. and S. Hagen (2016). Proceedings of EDULEARN16 conference. Barcelona, Spain.

Järvi, T. (2012). "Teaching Entrepreneurship in Vocational Education Viewed from the Regional and Field Perspectives." Journal of Vocational Education and Training (3): 365-377.

KD-KRD-NHD (2004). Se mulighetene og gjør noe med dem - strategiplan for entreprenørskap i utdanningen Retrieved from https://www.regjeringen.no/globalassets/upload /kd/vedlegg/grunnskole/strategiplaner/75561_entrepenorskap_strategi.pdf 03.03, 2020

KD-KRD-NHD (2009). "Handlingsplan for entreprenørskap i utdanningen." Retreived from http://www.regjeringen.no/upload/KD/Vedlegg/UH/Rapporter_og_planer/Entrepenorskap_09_nett. pdf. $03.03,2020$

Kunnnskapsdepartementet (2014). "Kvalifikasjonsrammeverket for livslang læring." Retrieved from 02.03, 2018.

Kvale, S., et al. (2009). Det kvalitative forskningsintervju. Oslo, Gyldendal akademisk.

Leffler, E. (2006). Företagsamma elever: diskurser kring entreprenörskap och företagsamhet i skolan. Umeå, Institutionen för matematik, teknik och naturvetenskap, Umeå universitet.

Polit, D. F. and C. T. Beck (2018). Essentials of nursing research : appraising evidence for nursing practice. Philadelphia, Pa, Wolters Kluwer.

Tuckman, B. W. and L. H. Humphreys (1965). "Developmental sequence in small groups." Psychological Bulletin 63(6): 384-399.

UE-Norge (2017). "Ungt Entreprenørskap sin pedagogiske plattform." Retrieved from https://www.ue.no/content/download/31790/255717/file/Pedagogisk\%20plattform\%20digital.pdf 06.05., 2017

Ødegård, I. K. R. (2000). Pedagogisk entreprenørskap: en innovasjonsstrategi i opplæring og utdanning. Kristiansand, Høyskoleforl.

Ødegård, I. K. R. (2003). Læreprosesser i pedagogisk entreprenørskap: å lære i dilemma og kaos. Kristiansand, Høyskoleforl

Ødegård, I. K. R. (2014). Pedagogisk entreprenørskap i lærerutdanning : en framtidsrettet læringsstrategi. Oslo, Cappelen Damm akademisk.

Ødegård, I. K. R. and A. M. S. Ask (2014). Entreprenørskap i skole og utdanning : aktiv, praktisk og meningsfull læring. Kristiansand, Portal. 